\title{
IMPLEMENTASI PENDIDIKAN AGAMA KRISTEN DI SLB NEGERI PEMBINA TINGKAT PROVINSI PAPUA KOTA JAYAPURA
}

\author{
The Implementation of Christian Education \\ at SLB (Special School) In Jayapura, Papua Province
}

\author{
Amiruddin \\ Balai Penelitian dan Pengembangan Agama Makassar \\ Jl. A.P Pettarani No. 72 Makassar \\ Email: amiruddinalbarru@yahoo.co.id
}

Naskah diterima tanggal 02 Juli 2015. Naskah direvisi tanggal 04 Agustus 2015. Naskah disetujui tanggal 02 November 2015

\begin{abstract}
Abstrak
Pendidikan agama merupakan bidang studi wajib di lembaga pendidikan dengan tujuan membantu peserta didik memperoleh kehidupan yang bermakna. Penelitian ini bertujuan untuk mengetahui gambaran deskriptif mengenai pendidikan Agama Kristen bagi anak difabel di Sekolah Luar Biasa, serta menemukan model pembelajaran yang tepat di SLB. Masalah yang diangkat adalah a) bagaimana pelaksanaan Pendidikan Agama Kristen di SLB, b) bagaimana konsep pendidikan agama bagi anak berkebutuhan khusus, serta c) apa yang menjadi faktor pendukung dan penghambat pelaksanaan pendidikan Agama Kristen di SLB. Penelitian ini menggunakan metode kualitatif melalui observasi sederhana terhadap pengelolaan SLB, wawancara singkat dengan kepala sekolah dan guru di SLB sasaran penelitian dan dokumentasi visual terhadap sarana dan prasarana SLB di Jayapura. Hasil dari penelitian ini adalah 1) pelaksanaan pendidikan agama belum sesuai dengan harapan, karena belum tersedia guru agama khusus yang memiliki kompetensi dibidang keagamaan, sehingga untuk mengisi kekosongan tersebut kepala sekolah menugaskan guru yang dianggap mampu untuk memberikan materi pendidikan agama. 2) konsep pembelajaran agama yang diterapkan dengan menggabungkan semua siswa difabel dalam satu kelas untuk semua tingkatan. Idealnya pembelajaran pendidikan agama di SLB dilakukan berdasarkan jenis difabel dengan pendekatan pembelajaran individual.
\end{abstract}

Kata kunci: implementasi, sekolah luar biasa, pendidikan agama Kristen

\begin{abstract}
Religious education is a compulsory subject in educational institutions to help students obtain a meaningful life. This study aims to identify descriptive overview about Christian education for children with disabilities in Special School, as well as to find appropriate learning models in the school. The issues raised are that a) how the implementation of Christian education in special school is, $b$ ) how the concept of religious education for children with special needs is, as well as c) What factors supporting and inhibiting the implementation of Christian education in the school are. This study employed qualitative method through simple observation to the Special School management, short interviews with principal and teachers in the targeted school and visual documentation of the infrastructure of Special School in Jayapura. The results of the study were 1) the implementation of religious education has not been in line with expectations, because there was not special religious teachers yet who have competence in the field of religion, so generally the principal assigned other teachers who were considered to be able to provide religious education materials 2). The concept of religious learning applied by gathering all of the students with disabilities in one class for all levels. Ideally, religious education teaching in special school is based on the type of disabilities with individualized learning approaches.
\end{abstract}

Keywords: implementation, diffabel, Christian religious education 


\section{PENDAHULUAN}

$\mathrm{P}$ endidikan merupakan kebutuhan bagi setiap umat manusia, baik yang normal maupun mereka yang mempunyai kelainan fisik atau mental. Pendidikan merupakan faktor yang sangat penting bagi kehidupan manusia. Dengan adanya pendidikan, manusia dapat berkembang sesuai dengan fitrahnya. Begitu juga dengan anak-anak berkebutuhan khusus, mereka berhak mendapatkan layanan pendidikan sebagaimana yang didapatkan oleh anak-anak normal. Pendidikan bagi anak berkebutuhan khusus bertujuan untuk membentuk siswa agar mampu berprestasi dalam kelompoknya, baik secara sosial maupun emosional sebatas kemampuannya (Nuraeni, 1997:104-105).

Hak untuk memperoleh pendidikan merupakan hak semua warga negara, tidak terkecuali anak berkebutuhan khusus. Hal ini telah ditegaskan dalam UUD 1945 pasal 31 maupun pada UU No. 20 tahun 2003 tentang Sistem Pendidikan Nasioanl pasal 5 ayat 2 yang dengan tegas menyatakan bahwa "warga negara yang memiliki kelainan fisik, emosional, mental, intelektual, dan/ atau sosial berhak memperoleh pendidikan khusus". Oleh karena itulah, sudah sewajarnya pemerintah dan kita semua memberikan perhatian yang baik terhadap penyelenggaraan pendidikan bagi anak berkebutuhan khusus.

Anak Berkebutuhan Khusus (ABK) juga mempunyai hak yang sama dalam masalah pendidikan. Agar anak berkebutuhan khusus mempunyai perkembangan yang wajar pada fungsi sosialnya, maka pendidikan yang diberikan tidak terbatas pada bimbingan kecerdasan dan keterampilan saja, tetapi juga bimbingan mental spiritual atau pendidikan agama. Pengamalan pendidikan agama akan berjalan dengan baik dengan mengacu pada 3 ranah (daerah binaan) yaitu ranah kognitif, afektif dan psikomotorik. Dalam melaksanakan pengajaran pendidikan agama pada SLB diperlukan persiapan yang baik, dalam hal materi, metode serta memahami keadaan peserta didik yang dalam hal ini para penyandang kelainan embisil (Aida Hikmawati: http://digilib.uin-suka. ac.id/4736/).

Pendidikan agama dalam sistem pendidikan nasional merupakan salah satu jenis pendidikan yang didesain dan diberikan kepada peserta didik untuk mengembangkan keberagamaan mereka (Thoha, 1999:4). Hal ini mengisyaratkan bahwa dalam sistem pendidikan ada keseimbangan antara pengembangan potensi fisik dan mental, potensi intelektual dan spiritual, sebagai esensial dalam pembangunan manusia Indonesia seutuhnya.

Pendididkan Agama sebagai salah satu mata pelajaran wajib untuk semua jenjang pendidikan dalam sistem pendidikan nasional, termasuk juga pendidikan bagi Anak Berkebutuhan Khusus (ABK) atau dalam pendidikan formal disebut Sekolah Luar Biasa (SLB). Materi Pendidikan Agama sarat dengan konsep-konsep abstrak yang harus dipahami peserta didik untuk pengembangan sikap beragama dalam kancah kehidupan bermasyarakat. Oleh karena itu, dalam pembelajaran pendidikan agama harus dapat diterapkan dalam kehidupan sehari-hari, baik dalam rangka penerapan ritual beragama, maupun dalam berperilaku hidup sesuai tuntunan dan ajaran agama.

Fakta di sebagian besar Sekolah Luar Biasa (SLB) di Indonesia, menunjukkan bahwa masih banyak guru pendidikan agama yang tidak memiliki kualifikasi bidang ke-PLB-an. Kelebihan guru tersebut menguasai substansi bidang pendidikan agama namun lemah dalam strategi, metode dan media pembelajarannya, serta pemahaman terhadap karakteristik ABK. Sementara itu prinsip kekonkritan sangat diperlukan ABK dalam belajar karena anak ABK yang bersekolah di SLB memiliki disabilitas yang berbeda-beda atau sebaliknya mereka menguasai strategi pembelajaran di SLB tapi tidak memiliki kualifikasi keilmuan tentang pendidikan agama. Realitas bahwa ada beberapa guru di Sekolah Luar Biasa (SLB) yang mengajarkan Pendidikan Agama yang bukan kompetensinya dan sebaliknya ada guru yang memiliki kompetensi kePLB-an yang baik namun tidak didukung dengan penguasaan pendidikan agama secara utuh.

Anak Berkebutuhan Khusus (ABK) atau anak luar biasa adalah anak dengan karakteristik khusus yang berbeda dengan anak pada umumnya tanpa selalu menunjukan pada ketidak mampuan mental, emosi atau fisik. Yang termasuk kedalam ABK atau kebutuhan khusus antara lain: tunanetra, tunarungu, tunagrahita, tunadaksa, tunalaras, kesulitan belajar, gangguan prilaku, anak berbakat, anak dengan gangguan kesehatan. Istilah lain bagi anak berkebutuhan khusus adalah anak luar biasa 
dan anak cacat. Karena karakteristik dan hambatan yang dimiliki, $\mathrm{ABK}$ memerlukan bentuk pelayanan pendidikan khusus yang disesuaikan dengan kemampuan dan potensi mereka, contohnya bagi tunanetra mereka memerlukan modifikasi teks bacaan menjadi tulisan Braille dan tunarungu berkomunikasi menggunakan bahasa isyarat. Anak berkebutuan khusus biasanya bersekolah di Sekolah Luar Biasa (SLB) sesuai dengan kekhususannya masing-masing. (Eltafiyanal Haqqo, 2010. http://lib. uin-malang.ac.id/?mod)

Penelitian ini mencoba mendalami keterlaksanaan Pendidikan Agama Kristen yang dilakukan oleh guru Agama di Sekolah Luar Biasa di Provinsi Papua dengan fokus penelitian pada pengembangan model pembelajaran Pendidikan Agama Kristen bagi Anak Berkebutuhan Khusus. Adapun pertanyaan penelitian ini adalah: 1) Bagaimanakah Pembelajaran Pendidikan Agama Kristen di SLB Negeri Pembina Tingkat Provinsi Papua Kota Jayapura? 2) Bagaimana model pembelajaran Pendidikan Agama Kristen yang dikembangkan oleh pendidik di SLB Negeri Pembina Tingkat Provinsi Papua Kota Jayapura?

Sejalan dengan rumusan masalah maka tujuan penelitian ini adalah: Adanya gambaran deskriptif mengenai pendidikan Agama Kristen bagi anak difabel di Sekolah Luar Biasa di Kota Jayapura secara khusus dan Provinsi Papua secara umum. Untuk mengetahui proses pembelajaran pendidikan agama Kristen dan menemukan model pembelajaran pada SLB di Kota Jayapura. Dan untuk mengetahui pengembangan model pembelajaran pendidikan Agama Kristen di SLB yang selanjutnya dapat direkomendasikan sebagai masukan kebijakan dalam peningkatan kualitas pendidikan agama Kristen di SLB.

\section{Tinjauan Pustaka}

Pendidikan agama adalah bahagian dari sistem pendidikan nasional. Peraturan Menteri Agama RI Nomor 16 Tahun 2010 tentang Pengelolaan Pendidikan Agama pada sekolah, pada Bab I pasal 1 ayat 1 disebutkan "pendidikan agama adalah pendidikan yang memberikan, pengetahuan dan membentuk sikap, kepribadian dan ketrampilan peserta didik dalam mengamalkan ajaran agamanya, yang dilaksanakan sekurang-kuranya melalui mata pelajaran pada semua jalur, jenjang dan jenis pendidikan.
Sekolah Luar Biasa adalah sekolah yang menyelenggarakan pembelajaran terhadap anak-anak difabel, disebabkan olah kekurangan kesempurnaan keadaan fisik maupun mental mereka, sehingga mereka menyandang ketunaan.

Anak penyandang ketunaan dapat diartikan sebagai anak cacat, anak luar biasa, anak berkelainan atau anak berkebutuhan khusus. Dalam bahasa Inggris anak penyandang ketunaan disebut sebagai handicapped children atau exceptional children. Menurut World Health Organization (WHO) handicap adalah sebuah keadaan merugikan yang dialami oleh individu sehingga mengakibatkan kelemahan atau ketidakmampuan serta membatasi peran individu (Abdurrahman, 2004:7-8). Termasuk kedalam golongan handicapped children diantaranya adalah buta, tuli, bentuk badan tidak normal, dan anak-anak yang mempunyai sifat-sifat jasmani yang tidak normal. Anak-anak penderita cacat jasmani secara psikis mengalami beberapa masalah yaitu biasanya mereka mengalami kelainan atau perubahan pada energi syarafnya.

\section{Jenis Disabilitas}

Ada dua pengertian yang saling berbeda antara anak-anak cacat dan anak yang menyandang ketunaan (handicapped) anak luar biasa atau anak berkelainan. Pada umumnya anak luar biasa dipandang identik dengan anak cacat. Sebenamya anak luar biasa atau berkelainan mencakup anak cacat dan anak yang memiliki bakat khusus pada salah satu bidang yang luar biasa hebat. Sedangkan anak-anak yang mempunyai kecerdasan sangat rendah, anak buta, atau anak tuli termasuk anak luar biasa atau berkelainan sekaligus juga anak cacat.

Anak-anak yang mempunyai gangguan perkembangan tersebut memerlukan suatu metode pembelajaran yang sifatnya khusus. Suatu pola gerak yang bervariasi, diyakini dapat meningkatkan potensi peserta didik dengan kebutuhan khusus dalam kegiatan pembelajaran (berkaitan dengan pembentukan fisik, emosi, sosialisasi, dan daya nalar).

Kekurangan secara fisik dan mental yang dimiliki oleh mereka pada umumnya menyebabkan mereka merasa tidak dibutuhkan. dan tidak bermanfaat bagi orang lain. Hal tersebut tentunya menghalangi proses sosialisasi mereka kepada masyarakat dalam bidang keintelektualan. Oleh 
karena itu, sebagian besar anak-anak penyandang ketunaan diarahkan pada masa depan pendidikan kejuruan atau ketrampilan. Tujuannya adalah agar mereka tidak merasa inferior dibandingkan dengan anak-anak normal.

Undang-Undang Sistem Pendidikan Nasional No. 20 tahun 2003 pasal 37 ayat (1) menegaskan bahwa isi kurikulum pendidikan dasar dan menengah wajib memuat, antara lain pendidikan agama (UUSPN No. 20 Tahun 2003), dan dalam pasal 30 ayat 2 menjelaskan bahwa pendidikan keagamaan berfungsi menyiapkan peserta didik menjadi anggota masyarakat yang memahami dan mengamalkan nilai-nilai ajaran agamanya dan/atau menjadi ahli ilmu agama.

Pendidikan agama sebagaimana dijelaskan dalam kurikulum 2004, adalah upaya sadar dan terencana dalam menyiapkan peserta didik untuk mengenal, memahami, menghayati hingga mengimani, bertaqwa dan berakhlak mulia dalam mengamalkan ajaran agama dari sumber utamanya, melalui kegiatan bimbingan, pengajaran, latihan, penggunaan pengalaman dan tuntutan untuk menghormati penganut agama lain dalam hubungannya dengan kerukunan antar ummat beragama dalam masyarakat hingga terwujud kesatuan dan persatuan bangsa.

Peraturan Menteri Agama Republik Indonesia Nomor 16 Tahun 2010 Tentang Pengelolaan Pendidikan Agama Pada Sekolah Pasal 16 Guru Pendidikan Agama harus memiliki kompetensi pedagogik, kepribadian, sosial, profesional, dan kepemimpinan.

Anak berkebutuhan khusus adalah anak dengan karakteristik khusus yang berbeda dengan anak pada umumnya tanpa selalu menunjukan pada ketidakmampuan mental, emosi atau fisik. Termasuk kedalam ABK antara lain: tunanetra, tunarungu, tunagrahita, tunadaksa, tunalaras, kesulitan belajar, gangguan prilaku, anak berbakat, anak dengan gangguan kesehatan.

\section{Tunanetra}

Tunanetra adalah individu yang memiliki hambatan dalam penglihatan. tunanetra dapat diklasifikasikan kedalam dua golongan yaitu: buta total (Blind) dan lowvision. Definisi Tunanetra menurut Kaufman \& Hallahan adalah individu yang memiliki lemah penglihatan atau akurasi penglihatan kurang dari 6/60 setelah dikoreksi atau tidak lagi memiliki penglihatan. Karena tunanetra memiliki keterbataan dalam indra penglihatan maka proses pembelajaran menekankan pada alat indra yang lain yaitu indra peraba dan indra pendengaran.

Oleh karena itu, prinsip yang harus diperhatikan dalam memberikan pengajaran kepada individu tunanetra adalah media yang digunakan harus bersifat aktual dan bersuara, contohnya adalah penggunaan tulisan braille, gambar timbul, benda model dan benda nyata. sedangkan media yang bersuara adalah tape recorder dan peranti lunak JAWS. Untuk membantu tunanetra beraktivitas di sekolah luar biasa mereka belajar mengenai orientasi dan mobilitas. Orientasi dan mobilitas diantaranya mempelajari bagaimana tunanetra mengetahui tempat dan arah serta bagaimana menggunakan tongkat putih (tongkat khusus tunanetra yang terbuat dari alumunium).

pendengaran individu tunarungu memiliki hambatan dalam berbicara sehingga mereka biasa disebut tunawicara. Cara berkomunikasi dengan individu menggunakan bahasa isyarat, untuk abjad jari telah dipatenkan secara internasional sedangkan untuk isyarat bahasa berbeda-beda di setiap negara.

Saat ini di SLB sedang dikembangkan komunikasi total yaitu cara berkomunikasi dengan melibatkan bahasa verbal, bahasa isyarat dan bahasa tubuh. Individu tunarungu cenderung kesulitan dalam memahami konsep dari sesuatu yang abstrak.

\section{Tunarungu}

Tunarungu adalah individu yang memiliki hambatan dalam pendengaran baik permanen maupun tidak permanen. Klasifikasi tunarungu berdasarkan tingkat gangguan pendengaran adalah: 1) Gangguan pendengaran sangat ringan (27-40dB);

2) Gangguan pendengaran ringan (41-55dB); 3) Gangguan pendengaran sedang (56-70dB); 3) Gangguan pendengaran berat (71-90dB); 4) Gangguan pendengaran ekstrem/tuli (di atas 91dB).

Tunarungu memiliki hambatan dalam berbicara sehingga mereka biasa disebut tunawicara. Cara berkomunikasi dengan individu menggunakan bahasa isyarat, untuk abjad jari telah dipatenkan secara internasional sedangkan untuk isyarat bahasa berbeda-beda di setiap negara. Saat ini di SLB sedang dikembangkan komunikasi total yaitu 
cara berkomunikasi dengan melibatkan bahasa verbal, bahasa isyarat dan bahasa tubuh. Tunarungu cenderung kesulitan dalam memahami konsep dari sesuatu yang abstrak.

\section{Tunagrahita}

Tunagrahita adalah individu yang memiliki intelegensi yang signifikan berada dibawah rata-rata dan disertai dengan ketidakmampuan dalam adaptasi prilaku yang muncul dalam masa perkembangan. Klasifikasi tunagrahita berdasarkan pada tingkatan IQ yaitu: 1) Tunagrahita ringan (IQ: 51-70); 2) Tunagrahita sedang (IQ: 36-51); 3) Tunagrahita berat (IQ: 20-35); 4) Tunagrahita sangat berat (IQ dibawah 20). Pembelajaran bagi individu tunagrahita lebih di titik beratkan pada kemampuan bina diri dan sosialisasi.

\section{METODE PENELITIAN}

Penelitian ini di lakukan di Provinsi Papua. Tepatnya di Kota Jayapura dengan sasaran penelitian diSLBN-B Kotaraja dan SLB Negeri Pembina Tingkat Provinsi Papua Jayapura. Penelitian ini merupakan penelitian kualitatif, dimana peneliti menjadi bagian dari key instrument (Bogdan, at.al, 1982: 27). Penelitian ini mencoba memperoleh gambaran jelas tentang keterlaksanaan pembelajaran pendidikan agama Kristen di SLB, kualifikasi dan kompetensi guru agama di SLB tersebut. Prosedur penelitian ini adalah dengan cara melakukan interpretasi terhadap deskriptif studi lapangan berupa strategi pembelajaran para guru yang mengajarkan agama Kristen yang mengajar di SLB setelah itu peneliti melakukan analisis untuk kemudian membuat generalisasi terhadap metode pengajaran para guru agama diSLB tersebut. Sumber data dalam penelitian ini dibagi menjadi dua yaitu sumber primer dan sekunder. Yang termasuk sumber primer disini adalah yang berhubungan langsung dengan obyek penelitian yaitu pendidik (guru) mata pelajaran Pendidikan Agama Kristen yang mengajar di SLB itu sendiri, karena penelitian ini tentang Pendidikan Agama maka secara tidak langsung guru-guru lainnya (di luar Guru Agama) yang memasukkan niali-nilai keagamaan juga menjadi masukan serta memberikan pengayaan pada penelitian ini. Sedangkan sumber sekunder dari penelitian ini adalah Warga sekolah terkait yakni Kepala SLB, orang tua siswa, serta dokumen-dokumen yang sifatnya sebagai pendukung. Instrumen-instrumen yang digunakan untuk menggali data dalam penelitian ini didapat dengan menggunakan beberapa teknik yaitu: a) Teknik observasi (pengamatan), b) Teknik interviu, c) Teknik dokumentasi, d) Analisis dan penafsiran data.

\section{PEMBAHASAN \\ Profil SLB Negeri Pembina Tingkat Provinsi Papua}

SLB Negeri Pembina Tingkat Provinsi Papua resmi didirikan pada tanggal 1 Mei 2000 berdasarkan SK Mendiknas Nomor 2188/II8.F/PD/2000. Melayani beberapa beberapa jenis kelainan/ ketunaan yaitu: tuna netra, tuna grahita, tuna daksa, tuna laras (campuran) dengan jenjang pendidikan mulai SDLB, SMPLB, dan SMALB. Fasilitas yang dimiliki antara lain di samping ruang belajar mengajar (ruangan kelas), juga terdapat beberapa fasiltias penunjang lainnya seperti perpustakaan digital, 7 (tujuh) unit ruangan keterampilan, serta asrama untuk siswa putra dan putri.

SLB Negeri Pembina Tingkat Provinsi Papua dengan alamat jalan Bumi Perkemahan Waena (Buper), Kecamatan Heram Kota Jayapura Papua kode pos 99538. Letaknya berada diatas bukit denga luas areal yang dimiliki 2 hektar Are (ha), dengan status kepemilikan oleh Dinas Pendidikan Pemuda dan Olahraga Provinsi Papua. SLB Negeri Pembina telah terakreditasi A oleh Badan Akreditasi Nasional

\section{Visi dan Misi}

Visi yang diembang oleh sekolah ini adalah untuk menjadikan SLB Negeri Pembina Tingkat Provinsi Papua sebagai sentra Pendidikan Khusus dan Pendidikan Layanan Khusus yang refresentatif di Provinsi Papua. Sedangkan untuk mewujudkan visi tersebut, maka sekolah menjabarkan ke dalam beberapa misi yang harus dilaksanakan, yaitu: Menciptakan manusia yang bertakwa kepada Tuhan Yang Maha Esa, berakhlak mulia, cakap, kreatif, dan mandiri. Mengembangkan potensi yang dimiliki, mengembangkan minat dan bakat siswa dalam bidang keterampilan, melengkapi sarana maupun prasarana, merekrut tenaga pendidik dan tenaga administrasi yang profesional di bidangnya, dan mengembangkan kemampuan sumber daya manusia yang ada. 


\section{Strategi Kebijakan}

Untuk mewujudkan visi, misi dan mencapai tujuan terutama yang berkaitan dengan penyelenggaraan pendidikan, pihak pimpinan telah menetapkan kebijakan yakni, meningkatkan mutu pelayanan pendidikan. Dengan demikian kepala sekolah selaku pimpinan tertinggi di SLB Negeri Pembina Tingkat Provinsi Papua memiliki komitmen dalam mengembangkan dan menerapkan Sistem Manajemen Mutu (SMM) secara berkesinambungan dengan: Senantiasa mengkomunikasikan kepada seluruh pegawai (tenaga pendidik dan tenaga administrasi) atas pentingnya memenuhi persyaratan pelanggan (baik siswa, orang tua siswa, maupun masyarakat luas) sebagai stakeholder serta memenuhi peraturan yang berlaku, menetapkan kebijakan mutu, sasaran mutu baik di tingkat sekolah maupun tingkatan urusan, senantiasa melakukan peninjauan terhadap aspekaspek yang terkait dengan ruang lingkup penerapan SMM, memastikan integrasi SMM terpelihara dan dikembangkan sesuai dengan perkembangan kegiatan sekolah

\section{Penyelenggaraan Pendidikan Agama Kristen Di SLB Negeri Pembina Tingkat Provinsi Papua}

Penyelenggaraan pendidikan agama khususnya pendidikan agama Kristen yang di implementasikan oleh SLB Negeri Pembina Tingkat Provinsi Papua dapat diungkap melalui komponen/ instrumen pembelajaran yang meliputi kondisi pendidik, peserta didik, kurikulum, metode dan model pembelajaran, serta sistem evaluasi yang diterapkan. Olehnya itu, akan di uraikan kondisi riil setiap komponen/instrumen pendidikan di SLB Negeri Pembina Tingkat Provinsi Papua sebagai berikut:

\section{Tenaga Pendidik}

SLB Negeri Pembina Tingkat Provinsi Papua menyadari bahwa peningkatan kompetensi tenaga pendidik dan kependidikan yang dimiliki menjadi proritas utama, karena merupakan tulang punggung organisasi dalam pengelolaan proses pendidikan. Oleh karean itu, kepala sekolah sangat memperhatikan kompetensi Sumber Daya Manusaia (SDM) dalam kaitannya dengan efektifitas implementasi Sistem Manajemen Mutu.

Jumlah tenaga pendidik yang dimiliki sebanyak 14 orang yang terdiri dari PNS sebanyak 7 orang dan Non PNS (honorer/GK) sebanyak 7 orang. Di lihat dari latar belakang pendidikannya pada umumnya sarjana ke PLB an bahkan terdapat 3 orang tenaga pendidik yang telah menyandang gelar magister, 6 orang menempuh pendidikan S1, terdapat 1 orang lulus D3, dan 3 orang yang lulusan SMK, serta 1 orang tenaga pendidik lulusan Alumni SLB ini yaitu bapak Ronald Rumkorem seorang tunanetra yang menjadi tenaga pendidik honorer di kelas tunanetra dan sebagai instruktur akufuntur/ refleksi. Berdasarkan jenis kelamin nampaknya persebarannya merata, yaitu 7 orang berjenis kelamin laki-laki dan 7 orang tenaga pendidik perempuan.

\section{Kompetensi Tenaga Pendidik Pendidikan Agama Kristen}

Temuan lapangan mengindikasikan bahwa tenaga pendidik yang mengajar pendidikan agama Kristen di SLB Negeri Pembina belum terpenuhi sesuai dengan harapan, dari tenaga pendidik yang kebetulan ditunjuk untuk mengajar pendidikan agama Kristen tidak memiliki kompetensi dibidang keagamaan, namum memiliki kompetensi di bidang ke PLB an karena 3 dari 4 guru agama tersebut adalah lulusan PLB. Hanya satu orang guru agama Kristen yang merupakan lulusan Sekolah Menengah Kejuruan (SMK).

Tenaga pendidik agama Kristen di SLB Negeri Pembinan Tingkat Provinsi Papua berjumlah empat (4) orang tenaga pendidik, dari ke empat tenaga pendidik agama Kristen tersebut bukanlah tenaga pendidik agama khusus, hanya diberikan tugas tambahan sebagai tenaga pendidik agama oleh kepala sekolah. Tenaga pendidik yang mengajar pendidikan agama Kristen mengalami kesulitan dalam memberikan materi pendidikan agama karena tidak memiliki kompetensi di bidang agama, apalagi yang diajar adalah siswa yang memiliki difabel yang membutuhkan penangananan khusus berbeda dengan siswa pada sekolah umum.

Secara kuantitas, tenaga pendidik yang tersedia di SLB Negeri Pembina ini masih kurang untuk ukuran sebuah sekolah yang berlabel pembina, nampaknya memang masih membutuhkan beberapa tenaga pendidik, dan yang paling prioritas adalah kehadiran tenaga pendidik khusus yang mengajarkan pendidikan agama (Islam, Kristen dan 
Katolik) untuk semua jenjang pendidikan (SDLB, SMPLB, SMALB).

Menurut informasi dari kepala sekolah (Tirsan Fien Gagola) terkait dengan ketersedian tenaga pendidik agama Kristen, beliau menuturkan bahwa:

"Di sini tidak ada tenaga pendidik khusus agama Kristen sama juga agama Islam. Kalau diagama kristen saya sendiri salah satunya tapi kita ada beberapa orang. Tingkat $S D$ nya ada 2 orang (Hamzal Lumele dan Ronald Rumkorem, SMPLB 1 orang (Tirsa Fien Gagola), dan SMALB 1 orang (Naomi Awoitau). jadi setiap jenjang sudah ada tenaga pendidik agamanya begitu juga untuk yang muslim ada juga tenaga pendidik agamanya tapi bukan tenaga pendidik agama khusus hanya kebijakan saya selaku kepala sekolah" (Wawancara, Tirsa: 15 April 2013).

Memang diakui bahwa dari 14 jumlah tenaga pendidik yang dimiliki oleh SLB Pembina ini terdapat 4 orang tenaga pendidik yang ditunjuk atau di beri tugas untuk mengajarkan mata pelajaran pendidikan agama yaitu, untuk jenjang SDLB kepala sekolah telah menugaskan bapak Hamzal Lumele dan Ronald Rumkorem. Pada tingkat SMPLB ibu kepala sekolah sendiri yang memberikan materi pendidikan agama Kristen, sedangkan pada jenjang SMALB tenaga pendidiknya adalah Naomi Awoitau.

Hamsal Lumele sebenarnya adalah Pegawai Honorer yang bertugas sebagai pegawai tata usaha, beliau bukan penduduk asli Papua tetapi beliau berasal dari Sulawesi selatan tepatnya di Kabupaten Tator yang merupakan salah satu kabupaten yang berada di Provinsi Sulawesi Selatan. Sedangkan Ronald Rumkorem adalah tenaga pendidik honorer dan merupakan alumni dari sekolah ini yang penyandang difabel tunanetra. Disamping mengajarkan mata pelajaran pendidikan agama Kristen pada tingkat SDLB, beliau juga sebagai koordinator akupuntur dan Refleksi bagi siswa difabel tunantra. Saat ini, Ronald sementara melanjutkan Pendidikannya di Universitas Cenderawasih (UNCEN) di Kota Jayapura dengan konsentrasi di jurusan Bimbingan dan Konseling (BK).

Sosok ibu Tirsa Fien Gagola memang memiliki nilai lebih dibanding dengan tenaga pendidik agama
Kristen lainnya di sampaing beliau adalah kepala sekolah yang merupakan lulusan PLB di manado, juga pengalaman mengajarnya di SLB \pm 20 tahun. Walaupun beliau secara kompetensi tidak pernah mengecam pendidikan Theologi tetapi beliau mampu memberikan pemahaman nilai-nilai agama kepada siswanya lewat sentuhan keuletan dan tak kenal lelah disaat mengajar pada semua jenis difabel.

Tampaknya tenaga pendidik yang ditugaskan oleh kepala sekolah untuk mengajar pendidikan agama Kristen walaupun secara kompetensi belum memenuhi harapan tetapi setidaknya usaha yang telah dilakukan oleh pihak sekolah untuk memberikan pembelajaran agama merupakan hal yang perlu diapresiasi. Setidaknya menurut penuturan ibu kepala sekolah selaku penanggung jawab bahwa secara substansial ketercapaian materi pelajaran agama yang sesuai dengan kurikulum belum bisa di penuhi, karena metode pembelajaran yang diberikan harus disesuaikan dengan kondisi siswa. Akan tetapi yang utama menurutnya bagaimana siswa tersebut bisa berprilaku yang baik dilingkungan sekolah maupun di masyarakat.

\section{Profil Peserta Didik (Siswa)}

Peserta didik yang ada di SLB Negeri Pembina berasal dari berbagai jenis difabel antara lain tunanetra, tunarungu, tunagrahita, tuna laras, cacat ganda, dan siswa autis. Berdasarkan data siswa, tampaknya dominan siswa yang menempuh pendidikan di SLB Negeri Pembina ini adalah penyandang difabel tunagrahita dan tunarungu.

Jumlah siswa yang di miliki untuk semua jenjang/tingkatan pendidikan (SDLB, SMPLB, SMALB) secara keseluruhan 97 siswa yang terdiri dari: a) jenjang SDLB memiliki siswa sebanyak 45 siswa, b) jenjang SMPLB memiliki siswa sebanyak 20 siswa, c) jenjang SMALB memiliki siswa sebanyak 13 siswa.

\section{Kurikulum}

Dalam konteks ini, SLB Negeri Pembina dalam perancangan dan/atau pengembangan kurikulum dilaksanakan secara periodik untuk memastikan pencapaian kompetensi siswa sesuai dengan harapan dan adaftif dengan perkembangan ilmu pengetahuan dan teknologi sesuai dengan tuntutan dunia usaha/dunia industri. SLB Negeri Pembina Tingkat Provinsi Papua menjamin bahwa 
proses perencanaan dan/atau pengembangan kurikulum dilaksanakan oleh tenaga-tenaga tenaga pendidik/pengajar yang kompeten, melalui tahapan proses yang memadai. Hasil perancangan dan/ atau pengembangan diferivikasi oleh tenaga yang berkompeten dan obyektif. Output kurikulum yang dihasilkan dipastikan disahkan oleh dinas pendidikan sebelum diterapkan dalam proses pendidikan.

Kurikulum yang digunakan di SLB Negeri Pembina Tingkat Provinsi Papua adalah kurikulum KTSP yang telah diberlakukan sejak tahun 2006. Kurikulum yang ada pada satuan pendidikan SLB sama dengan kurikulum sekolah pada umumnya. Hanya saja tenaga pendidik yang melakukan inovasi pembelajaran di dalam kelas dengan cara menyederhanakan atau menyesuaikan dengan kondisi dan kemampuan siswa. Penjabaran kurikulum tersebut oleh setiap tenaga pendidik di susun menjadi bahan ajar dalam bentuk Silabus dan RPP yang menyesuaikan dengan kondisi peserta didik di kelas.

\section{Perencanaan Pembelajaran Pendidikan Agama Kristen}

Proses pembelajaran yang baik hanya dapat diciptakan melalui perencanaan pembelajaran yang baik dan tepat. Perencanaan pembelajaran merupakan salah satu alat yang penting bagi tenaga pendidik untuk menciptakan pembelajaran yang maksimal. Tenaga pendidik yang baik akan selalu membuat perencanaan pembelajaran sebelum mengajar di kelas, dan tidak ada alasan mengajar tanpa perencanaan pembelajaran.

\section{Pengembangan Silabus}

Pengembangan silabus yang dilakukan oleh tenaga pendidik khususnya tenaga pendidik pendidikan agama Kristen di SLB Negeri Pembina Tingkat Provinsi Papua mengacu pada Pedoman Penyusunan KTSP oleh Badan Standar Pendidikan Nasional (BSPN) adalah rencana pembelajaran pada suatu dan/atau kelompok mata pelajaran/ tema tertentu yang mencakup standar kompetensi, kompetensi dasar, materi pembelajaran, kegiatan pembelajaran, indikator pencapaian kompetensi, penilaian, alokasi waktu, dan sumber belajar.

Analisis perangkat pembelajaran yang telah dilakukan oleh tenaga pendidik agama Kristen di SLB Negeri Pembina telah dijabarkan sesuai dengan pedoman yang merujuk kepada kurikulum KTSP tahun 2006. Namun pada implementasinya ketercapaian Kriteria Ketuntasan Minimal (KKM) terkadang tidak dicapai secara optimal dengan yang telah direncanakan, hal ini disebabkan kondisi peserta didik di SLB membutuhkan strategi khusus dalam penerapan pembelajaran di kelas, yang berbeda dengan peserta didik pada sekolah umum.

Dalam satu kompetensi dasar misalnya, didalam silabus telah ditentukan ketuntasannya akan dicapai pada beberapa kali pertemuan. Tapi hal itu tidak dapat di maksimalkan oleh tenaga pendidik karena untuk pencapaian kompetensi dasar tersebut harus dilakukan berulang-ulang sampai peserta didik yang mengalami difabel dapat memahaminya.

Hal ini sejalan apa yang diungkapkan oleh ibu Tiersa Fien Gagola selaku tenaga pendidik agama Kristen sekaligus sebagai kepala sekolah di SLB Negeri Pembina ini dengan mengatakan bahwa: "Silabus dan RPP khususnya untuk mata pelajaran pendidikan agama Kristen yang dibuat oleh merupakan kewajiban karena hal itu merupakan SIM nya tenaga pendidik. Dia tidak dapat mengajar tanpa perangkat tersebut. Akan tetapi apa yang tertuang dalam silabus dan RPP pendidik terkadang tidak sesuai dengan yang diajarkan". (wawancara, 15 April 2013)

Secara substansial, bahwa yang telah dilakukan oleh tenaga pendidik bila di telaah dari silabus dan RPP yang sudah ada dan dikembangkan oleh setiap pendidik mata pelajaran pendidikan agama Kristen telah sesuai dengan pedoman dalam buku panduan pengembangan silabus. Namun jika di lihat dari isi atau muatan yang ada di dalam silabus dan RPP yang telah di buat oleh pendidik tersebut, nampaknya tidak selalu bisa disampaikan secara maksimal karena daya serap peserta didik dengan berbagai latar difabel menjadi kendala utama dalam menuntaskan materi sesuai dengan yang telah digariskan dalam silabus dan RPP, sehingga apa yang telah tersusun dalam silabus dan RPP harus di kaji ulang oleh pendidik, disinilah dibutuhkan kreativitas dan inovasi tenaga pendidik dalam memberikan materi pendidikan agama pada peserta didik agar ketercapaian tersebut dapat di tuntaskan.

\section{Rencana Pelaksanaan Pembelajaran (RPP)}

Penyusunan Rencana Pelaksanaan

Pembelajaran (RPP) yang dilakukan oleh pendidik 
mengacu pada format atau model RPP yang telah tetapkan oleh BSPN. Dalam menyusun RPP ada beberapa indikator-indikator yang perlu untuk dilakukan analisis. Indikator yang dimaksud seperti yang tertuang dalam RPP sebagai berikut:

\section{Mendeskripsikan Tujuan pembelajaran}

Mendeskripsikan tujuan pembelajaran terfokus pada ketiga aspek domain sudah dirumuskan yaitu ketercapaian pada aspek kognitif, afektif, dan psikomotorik. Nampaknya dari ke tiga aspek tersebut, penekanannya lebih difokuskan pada aspek afektif yaitu mengukur sikap dan prilaku siswa dalam proses pembelajaran dan aspek psikomotorik berorientasi pada keterampilan atau skill. Hal ini dilakukan mengingat pembelajaran pendidikan agama Kristen lebih banyak berorientasi pada penanaman nilai-nilai keagamaan dengan membentuk watak, sikap dan perilaku siswa penyandang difabel agar dapat mengembangkan kepribadian yang baik dan di implementasikan dalam kesehariannya. Di samping itu siswa di SLB itu adalah penyandang difabel yang tentunya memiliki keterbatasan dalam menerima dan mencerna materi pelajaran. Olehnya itu, dalam merumuskan tujuan pembelajaran disesuaikan dengan kondisi dan kemampuan siswa.

Hasil pengamatan terhadap pembelajaran pendidikan agama Kristen di kelas V SDLB, pendidik membahas salah satu kompetensi dasar yang terkait dengan "Perbuatan Dosa yang di lakukan oleh manusia", sehingga yang menjadi tujuan yang diharapkan dalam kegiatan pembelajaran tersebut adalah "Siswa dapat membedakan sikap yang benar dikehendaki Allah dan sikap yang tidak dikehendaki Allah".

\section{Memilih/Menentukan Materi}

Bahan atau materi pelajaran adalah segala sesuatu yang menjadi isi kurikulum yang harus dikuasai oleh siswa sesuai dengan kompetensi dasar dalam rangka pencapaian standar kompetensi setiap mata pelajaran. Materi pelajaran merupakan bagian terpenting dalam proses pembelajaran. Sebagaimana pembahasan kompetensi dasar tentang perbuatan dosa manusia, maka materi yang di pilih oleh tenaga pendidik tentu hal-hal yang berhubungan dengan perbuatan dosa seperti yang telah di tuangkan dalam RPP antara lain: Tidak taat adalah awal dosa, Allah tidak berkenan pada kesombongan, Allah tidak suka pada ketidakjujuran, Marah yang mengakibatkan dosa, Allah marah terhadap keserakahan, Tindakan Allah terhadap dosa, Menjelaskan awal kejatuhan manusia dalam dosa. Referensi Alkitab, Kejadian 3; Roma 3: 23;6:23 1 Sam 17: 4 - 10; Kis 5: 1 - 11; Mrk 7: 20-23; 1 Raj 21: 1 - 6; Yer 1710

Menentukan materi pelajaran yang terkait dengan perbuatan dosa tersebut menunjukkan bahwa pendidik telah memilih dan menentukan materi pelajaran yang di rencanakan dalam RPP sudah sesuai, namun pemilihan materi belum maksimal hal ini dapat di lihat dari pengembangan materi yang direncanakan itu belum dikembangkan karena buku-buku yang menjadi sumber referensi masih kurang tersedia di perpustakaan, materi pelajaran pada umumnya berpedoman pada buku ajar yang bersumber dari buku-buku paket Pendidikan Agama Kristen (PAK) yang dipelajari oleh siswa SD pada umumnya, tidak ada buku paket tersendiri yang disediakan khusus untuk siswa penyandang difabel sehingga pendidik harus menyederhanakan materinya. Kondisi seperti ini menyulitkan pendidik dalam mengembangkan materi pelajaran yang akan disampaikan kepada peserta didik sesuai dengan indikator yang ingin dicapai.

Kenyataan ini memang di akui oleh salah seorang pendidik yang merangkap sebagai pendidik agama Kristen bapak Hamzal Lumele dengan mengatakan bahwa: "Buku rujukan dalam pembelajaran agama kristen sama seperti di sekolah umum tinggal disederhanakan, seperti untuk kelas VII SMPLB buku rujukannya Sahabat Sejati 1 yang ditulis oleh Aprianus dkk, sedangkan untuk Siswa SDLB memakai buku dengan judul "Tuhan Menolongku” karangan Edy Satriyo dkk. (Hamzal Lumele, 16 April 2013).

\section{Pelaksanaan Pembelajaran}

Secara umum pendidik agama Kristen di SLB Negeri Pembina Tingkat Provinsi Papua dalam melaksanakan proses pembelajaran di kelas di lakukan secara bertahap dengan durasi yang telah ditetapkan dalam RPP. Pelaksanaan pembelajaran merupakan rangkaian kegiatan yang dilakukan secara berkesinambungan meliputi tahap kegiatan awal, kegiatan inti, dan kegiatan akhir. 


\section{Kegiatan Pendahuluan}

Rangkaian pembelajaran diawali dengan kegiatan pendahuluan sebagai langkah awal yang dilakukan oleh tenaga pendidik sebelum memberikan materi pelajaran. Kegiatan ini berlangsung selama antara 7 sampai 10 menit. Pada kegiatan awal, tenaga pendidik melakukan persiapan pembelajaran seperti;

Membangkitkan Motivasi, sebelum kegiatan pembelajaran di mulai terlebih dahulu mengatur tempat duduk peserta didik yang akan menerima pelajaran, peran pendidik di sini sangat menentukan dalam mengelola kelas agar suasana pembelajaran dapat berjalan dengan baik, nampaknya anak difabel harus didekati satu persatu dalam mengatur tempat duduknya agar tidak saling mengganggu. Pendidik memulai kegiatan pendahuluan pada saat konsentrasi peserta didik siap untuk menerima pelajaran

Mengucapkan Salam; yang menjadi kebiasaan oleh setiap guru dalam membuka pelajaran selalu mengucapkan salam, karena pembelajaran ini adalah materinya pendidikan agama Kristen, maka salam pembuka yang diucapkan adalah "Selamat Pagi anak-anak, apakah sudah siap untuk belajar agama pada pagi hari ini”

Berdoa diawal pembelajaran; sebelum mengawali proses pembelajaran semua peserta didik melakukan do’a bersama yang di pimpin oleh pendidik, dan do' a yang di ucapkan oleh pendidik tersebut di ikuti oleh peserta didik secara bersamasama, dan do'a yang di ucapkan adalah:"Terima kasih Tuhan engkau telah memberikan kami kekuatan dan kesehatan untuk menerima pelajaran pagi hari ini, saat ini kami mau belajar agama berkatilah kami semua, supaya mendapat nikmati dari tuhan agar kami dapat menerima pelajaran agama pada pagi hari ini, dan dalam nama Yesus kami berdo'a haleluya, amin".

Membaca Al-Kitab; setiap materi pendidikan agama Kristen selalu merujuk pada ayat atau surat yang terdapat di dalam Al-Kitab, seperti pada beberapa pembelajaran agama Kristen yang sempat penulis amati setiap pokok bahasan selalu ada ayat dalam Al-Kitab yang harus di hafalkan oleh peserta didik seperti pada saat pembelajaran agama di kelas VII SMPLB dengan materi pelajaran "Perbuatan dosa yang dilakukan oleh manusia", maka ayat yang berkenaan dalam Al-Kitab adalah
Amsal 4:23 yang berbunyi, "Jagalah hatimu dengan segala kewaspadaan karena dari situlah terpancar kehidupan". Sedangkan materi pelajaran agama di Kelas V SDLB yaitu "Tuhan Mengampuniku” ayat yang dijadikan rujukan adalah Amsal 5:21 yang berbunyi: "Karena segala jalan orang terbuka di depan mata dan segala langkah orang diawasinya" Begitupun pada kelas II SDLB dengan materi pelajaran agama "Tuhan mencintai Suku bangsa" ayat rujukannya adalah Amsal 6: 6 berbunyi: "Hai Pemalas, pergilah kepada semut, lihat tingkahnya. Jadilah bijak". Inti dari kegiatan pendahuluan dimaksudkan sebagai kegiatan awal untuk mengkondisikan peserta didik agar perhatian dan motivasinya tumbuh, sehingga baik secara fisik maupun psikis memiliki kesiapan untuk melakukan kegiatan pembelajaran.

\section{Kegiatan Inti (PBM)}

Pembelajaran adalah komunikasi dua arah yang dilakukan oleh pendidik dengan peserta didik. Menurut Carcy, pembelajaran adalah suatu proses di mana lingkungan seseorang secara sengaja diokelola untuk memungkinkan ia turut serta dalam tingkah laku tertentu dalam kondisi-kondisi khusud atau menghasilkan respon terhadap situasi tertentu. (Mulyono, 1994: 7).

Kegiatan inti merupakan proses pembelajaran untuk mencapai kompetensi dasar dimana pendidik melakukan penyajian informasi dalam bentuk aktivitas-aktivitas yang dapat memudahkan peserta didik dalam memahami materi pelajaran, pada kegiatan ini, tergambar metode dan strategi pembelajaran yang digunakan oleh pendidik dalam kegiatan pembelajaran.

Hasil pengamatan penulis pada hari Senin, 15 April 2013 yang bertepatan dengan pelaksanaan Ujian Nasional Tingkat SMA terhadap pembelajaran pendidikanagama KristentingkatSDLBmenemukan fakta bahwa sistem pembelajaran yang diterapkan menurut hemat penulis tidak sesuai dengan tuntutan peningkatan kualitas pendidikan secara nasional karena proses pembelajaran pendidikan agama di lakukan secara klasikal dengan menggabungkan seluruh siswa SDLB mulai dari kelas 1 sampai kelas VI, untuk semua jenis difabel. Padahal idealnya sistem pembelajaran di SLB harus di pisahkan menurut tingkatan kelasnya dan menurut jenis difabelnya, serta metode pembelajaran seharusnya 
di lakukan dengan pendekatan individual.

Menurut penuturan kepala sekolah (Tirsa Fien Gagola) yang sekaligus juga mengajar mata pelajaran agama Kristen mengatakan bahwa: "Sebenarnya kami menyadari bahwa sistem pembelajaran seperti ini tentu tidak maksimal penerapannya, akan tetapi kami juga menyadari bahwa hal seperti ini kami lakukan karena di sekolah kami tidak memiliki tenaga pendidik khusus pendidikan agama, kami hanya memberikan tugas tambahan kepada tenaga pendidik yang kami anggap mampu untuk memberikan materi pendidikan agama, itupun tenaga pendidiknya sangat terbatas dari aspek kompetensi pemahaman keagamaannya. Materi pendidikan agama dilakukan secara serentak pada hari senin, baik materi agama Kristen maupun materi agama Islam didalam satu ruangan. Yang terpenting bagi kami dalam memberikan pendidikan agama khususnya pendidikan agama Kristen tidaklah muluk-muluk, kami hanya menanamkan nilai-nilai keagamaan, dan bagaimana siswa dapat berperilaku yang santun, baik dilingkungan sekolah maupun di masyarakat" (Wawancara, Tirsa, 15 April 2013).

\section{Membuka Pelajaran}

Membuka pelajaran dimaksudkan sebagai kegiatan awal untuk mengkondisikan peserta didik agar perhatian dan motivasinya tumbuh, sehingga baik secara fisik maupun psikis memiliki kesiapan untuk melakukan kegiatan pembelajaran. Membuka pelajaran cukup penting untuk diperhatikan karena biasanya penampilan dan kesan pertama akan berpengaruh pada kegiatan-kegiatan berikutnya, membuka pelajaran bertujuan agar peserta didik fokus pada pelajaran yang akan mereka terima.

Berdasarkan hasil observasi terhadap kegiatan pembelajaran pendidikan agama Kristen yang dilakukan oleh Hamzal Lumele dan Ronald Rumkoren pada hari Selasa, tanggal 16 April 2013 jam 09.00-10.00 pada tingkatan SDLB menunjukkan bahwa pada saat membuka pelajaran dilakukan dengan mempersiapkan siswa untuk mengikuti pelajaran dengan melakukan tegur sapa "selamat pagi", lalu melakukan apersepsi dengan menanyakan hal-hal yang berkaitan dengan materi pelajaran sebelumnya, lalu menyampaikan kompetensi dasar dan tujuan pembelajaran serta pokok-pokok materi yang akan di pelajari, sebelum menyajikan materi pelajaran terlebih dahulu mengecek kesiapan alat yang dibutuhkan seperti buku pelajaran agama Kristen, Al-Kitab.

\section{Menyajikan Materi}

Penyajian materi dalam kegiatan pembelajaran merupakan kegiatan inti pada saat inilah terjadi interaksi antara guru dengan siswa. Penyajian materi pelajaran dilakukan secara sistematis dengan menggunakan komunikasi total atau model percakapan MMR (Metode Meternal Reflektif) untuk semua anak difabel dan dibantu dengan penggunaan bahasa isyarat bagi anak difabel tunarungu.

Karena sistem pembelajaran yang diterapkan adalah klasikal dengan mengabungkan semua siswa di setiap tingkatan, (SDLB, SMPLB, dan SMALB), maka pendidik tentu merasa kesulitan untuk menuntaskan materi yang akan diberikan. Misalkan materi untuk kelas II tentu berbeda dengan materi di kelas V SDLB, begitupun buku paket yang di pakai juga berbeda, hal ini akan berpengaruh kepada daya serap peserta didik yang notabenenya anak difabel yang memiliki daya tangkap dalam menerima pelajaran dibawa rata-rata (khususnya siswa tunagrahita).

Ketidakmaksimalan penyajian materi pendidikan agama Kristen diperparah oleh sistem pengajaran terhadap anak difabel yang semestinya diberikan berdasarkan jenis kedifabelan dengan metode pendekatan individual, justru penerapan pembelajarannya dengan menggabungkan antara anak difabel tunarungu, tunagrahita, netra, dan autis secara bersama-sama.

Menurut penuturan Hamzal Lumele bahwa harus akui bahwa dalam memberikan materi pelajaran agama Kristen kepada siswa yang berkebutuhan khusus membutuhkan kesabaran karena konsentrasi mereka dalam menerima pelajaran sangat lamban sehingga di butuhkan pendekatan individual. Belum lagi ketika proses pembelajaran berlangsung, dominan anak difabel suka melakukan aktivitas sendiri atau menganggu temannya yang sementara konsentarasi belajar. Kalau sudah terjadi hal seperti ini membuat konsentrasi siswa lain menjadi buyar dan otomatis proses pembelajaran menjadi terganggu, dan untuk membangkitkan kembali konsentrasi peserta didik untuk menerima pelajaran dibutuhkan kesabaran oleh si pendidik dalam memotivasi dengan pendekatan indivual. (Wawancara, 16 April 2013). 
Memang diakui bahwa dalam menyampaikan materi kepada peserta didik tentu berbeda pendekatannya untuk setiap anak difabel seperti tunarungu dengan tunagrahita dan anak difabel lainnya. Khusus untuk tuna rungu dalam penyampaian materi dibutuhkan keahlian khusus di samping harus menguasai bahasa isyarat, juga mempergunakan mimik artinya mulut harus di fungsikan secara pelan untuk melafalkannya harus jelas agar apa yang disampaikan bisa dipahami oleh siswa begitu juga gerakan tubuh sangat berperan dalam menyampaikan materi.

Sehingga dalam penyampaian materi pendidikan agama Kristen penekanannya hanya terfokus pada konsep dasar, yang penting siswa dapat bersikap dan berperilaku yang baik, mengerti tata cara berdoa, utamanya doa untuk Bapak kami, dan Pengakuan imam Rasuli, serta bisa membuka dan membaca Al-Kitab, rajin ke gereja setiap minggu.

Materi agama yang di berikan di sekolah dapat di implementasikan atau dipraktekkan di gereja. Mereka tidak dituntut untuk mengerti tentang hakekat orang beragama secara filosofi dan secara theologis, tapi yang terpenting bagaimana anak difabel tersebut dapat mengamalkan nilainilai agama Kristen secara baik di dalam kehidupan kesehariannya. Pendidik dalam menyajikan meteri juga melibatkan peserta didik dengan mengajukan pertanyaan kepada peserta didik mengenai apa yang telah disampaiakan, atau mempersilahkan peserta didik mengajukan pertanyaan mengenai materi pelajaran yang belum dipahami. Dalam melibatkan peserta didik guru sering memberikan penguatan dengan kata-kata: baik, betul, dan tepat sekali.

Materi pendidikan agama Kristen yang diberikan lebih banyak terfokus pada penanaman nilai, sikap dan perilaku yang sesuai dengan tuntutan agama Kristen sebagaimana diperintahkan oleh Yesus Kristus. Olehnya itu, penekanan yang mendasar dalam pembelajaran agama Kristen di SLB ini menitik beratkan pada kemampuan peserta didik dalam mempraktekkan tata cara berdoa, baik doa pada saat memulai dan mengakhiri pembelajaran, maupun kemampuan peserta didik dalam menghafal doa Bapak Kami. Setiap peserta didik diwajibkan untuk melakukan do'a sebelum dan sesudah menerima pelajaran, di samping itu peserta didik juga wajib menghafalkan doa Bapak
Kami. Maka tidak heran kalau doa Bapak kami di SLB ini sangat populer dan nampaknya setiap peserta didik sudah menghafal doa tersebut.

Dalam Al-Kitab, doa Bapak kami terdapat pada kitab Matius 6: 9-13 yang berbunyi: "Bapak kami yang ada disurga di kuduskanlah namaMu, datanglah KerajaanMu, jadilah kehendakMu di bumi seperti di surga. Berikanlah kami rejeki pada hari ini, makanan kami yang secukupnya. Dan ampunilah kesalahan kami, seperti kami juga mengampuni orang yang bersalah kepada kami. Dan juga membawa kami kedalam pencobaan, tetapi bebaskanlah kami dari pada yang jahat. Karena engkaulah yang empunya kerajaan, dan kuasa dan kemuliaan sampai selama-lamanya. Amin.

\section{Penggunaan Metode Pembelajaran}

Penggunaan metode yang tepat akan turut menentukan efektivitas dan efesiensi pembelajaran. Oleh karena itu, metode pembelajaran harus dipilih dan dikembangkan untuk meningkatkan aktivitas dan kreativitas peserta didik. Metode pelajaran harus dipahami oleh pendidik agar dapat memilih metode sesuai dengan kebutuhan. Penggunaan metode pembelajaran yang tepat dapat melaksanakan pembelajaran secara efektif dalam meningkatkan hasil pembelajaran.

Anak difabel adalah anak yang memerlukan penanganan khusus sehubungan dengan gangguan perkembangan dan kelainan yang di alami sehingga untuk belajar pun menggunakan metode khusus, seperti mata pelajaran agama Kristen diperlukan metode khusus dalam menyampaikan materi pelajaran untuksetiapjenis difabel.Sebutlah misalnya untuk tunarungu pendidik harus menggunakan alat bantu tangan sebagai bahasa isyarat, mulut sebagai alat untuk membiasakan siswa tunarungu berbicara, dan gerakan tubuh sebagai bahasa verbal. Lain lagi untuk siswa yang mengalami gangguan mental seperti tunagrahita yang memiliki kemampuan dibawah rata-rata sudah barang tentu pendidik harus melakukan pendekatan khusus yang berbeda dengan siswa tunanetra yang memiliki kemampuan dalam menerima pelajaran jauh lebih bagus, tapi kurang dari aspek penglihatan. Oleh karena itu setiap pendidik khususnya pendidik agama harus menguasai metode pada setiap anak difabel agar materi yang disampaikan mudah diterima dan proses pembelajaran bisa berjalan sebagaimana 
mestinya sehingga tujuan pendidikan khususnya pendidikan agama bisa tercapai.

Dominan metode yang diterapkan oleh pendidik agama kristen adalah metode ceramah, tanya jawab, diskusi, dan bercerita dengan menggunakan metode komunikasi total atau metode percakapan dengan istilah MMR (Maternal Metode Reflektif), metode ini dianggap paling efektif terutama mereka yang mengalami tunarungu, karena bahasa yang disajikan sewajar mungkin pada anak, baik secara ekspresif maupun reseptifnya. Kemampuan pendidik dalam menerapkan metode tampaknya cenderung monoton, hanya terfokus pada metode ceramah saja sehingga yang aktif adalah pendidik, padahal idealnya penggunaan metode yang diberikan harus bervariasi dengan mengembangkan keaktifan peserta didik untuk berintraksi dengan pendidik.

\section{Penggunaan Media Pembelajaran}

Media pembelajaran adalah peralatan dan perlengkapan yang secara langsung dipergunakan dalam proses pembelajaran. Melalui media pembelajaran pendidik dapat menyajikan bahan pelajaran yang bersifat abstrak menjadi konkret sehingga mudah dipahami dan dapat menghilangkan verbalisme. Penyampaian informasi yang hanya melalui bahasa verbal dapat menimbulkan kesalahan persepsi siswa.

Media pembelajaran yang dipergunakan dalam proses pembelajaran agama Kristen masih terbatas seperti gambar-gambar yang berkaitan dengan materi pelajaran yang di peroleh lewat internet, seperti gambar rumah ibadah, gambar sosok Yesus Kristus, lembaran kertas dengan beberapa kalimat yang diacak kemudian mencari kalimat yang berhubungan berbuatan baik. Selain media pelajaran pendidik juga menggunakan sumber belajar berupa buku paket Pendidikan Agama Kristen (PAK) tingkat SD, dan Al-Kitab yang menjadi rujukan pokok dalam pembelajaran pendidikan agama Kristen. Di samping itu, pendidik juga sudah mempergunakan media pembelajaran dengan pendekatan teknologi berupa komputer/ laptop. Pendidik dalam menyajikan materi pelajaran dalam bentuk cerita bergambar melalui powerpoint. Cerita yang diangkat pada saat pembelajaran tersebut adalah kisah Yesus dan Zakheus.
Ringkasan cerita Al-Kitab ini mengatakan pada kita tentang Allah kita yang hebat yang telah menciptakan kita dan ingin kita mengenal Dia. Allah tahu kita telah berbuat hal yang buruk, yang Ia sebut dosa. Hukum dosa adalah maut, tapi Allah sangat mengasihi kita. Ia mengutus putraNya Yesus untuk mati di kayu salib dan dihukum karena dosa-dosa kita. Kemudian Yesus hidup kembali dan pergi ke Surga! Jika kamu percaya pada Yesus dan minta Dia mengampuni dosa-dosamu, Ia akan melakukannya! Ia akan datang datang dan tinggal di dalammu sekarang, dan kamu akan hidup bersama Dia selamanya. Jika kamu ingi berbalik dari dosadosamu katakan ini pada Allah: "Allah yang baik, aku percaya bahwa Yesus telah mati untukku, dan sekarang hidup kembali. Datanglah dalam hidupku dan ampunilah dosa-dosaku, agar aku dapat memiliki hidup yang baru sekarang, dan suatu saat nanti pergi bersamaMu selamanya. Tolonglah aku untuk hidup bagiMu sebagai sebagai anakMu. Amin" (Yohanes:3: 16)

\section{Pengelolaan Kelas}

Pengelolaan kelas merupakan salah satu hal penting yang perlu mendapat perhatian. Karena sebaik apapun metode dan media yang digunakan dalam kegiatan pembelajaran tetapi penguasaan kelas tidak maksimal maka akan berpengaruh terhadap pencapaian tujuan yang telah ditetapkan. Adapun tujuan pengelolaan kelas adalah agar setiap peserta didik di kelas dapat belajar dengan tertib sehingga tercapai tujuan pengajaran secara efektif dan efesien.

Pendidik sebelum memberikan materi pelajaran terlebih dahulu mengelola kelas dengan cara mengatur tempat duduk para peserta didik sesuai dengan jenis kedifabelan, dengan tujuan agar tidak saling menganggu. Posisi kursi dan meja menghadap ke depan berhadapan dengan meja pendidik agar peserta didik dapat dengan muda melihat dan mendengarkan penjelasan materi baik lewat mimik, gerakan isyarat, maupun bahasa verbal yang diperagakan oleh pendidik.

Walaupun demikian, pengelolaan kelas yang dilakukan oleh pendidik belumlah maksimal, hal ini dapat dilihat masih ada beberapa peserta didik yang selalu mondar-mandir keluar ruangan, asyik dengan kegiatannya sendiri pada waktu guru menjelaskan materi pelajaran, tidak memperhatikan dengan 
baik pada waktu guru mendemonstrasikan materi pelajaran yang akan diperaktekkan, bahkan ada peserta didik yang menangis di dalam kelas.

Walaupun pendidik sudah berusaha mengelola kelas dengan baik dengan cara mendekati peserta didik untuk berhenti menangis, mengajukan pertanyaan kepada peserta didik namun tetap saja ada yang tidak mengikuti dengan baik apa yang disampaikan oleh guru. Hal ini dikarenakan karakteristik anak difabel itu memiliki keunikan tersendiri yang dalam penanganannya harus dilakukan dengan pendekatan individual dengan penuh kesabaran.

\section{Kegiatan Penutup}

Diakhir proses pembelajaran, pendidik melakukan kegiatan penutup yang dilakukan selama 10 menit. Aktifitas yang dilakukan oleh siswa pada saat kegiatan akhir proses pembelajaran yaitu:

Menyimpulkan Pelajaran: Menyimpulkan pelajaran adalah kegiatan yang dilakukan oleh pendidik untuk memberikan gambaran yang menyeluruh tentang apa yang telah dipelajari oleh peseta didik, mengetahui tingkat pencapaian pemahaman peserta didik, dan tingkat keberhasilan pendidik dalam proses pembelajaran.

Memberikan Umpan Balik: Umpan balik merupakan kegiatan yang dilakukan oleh pendidik dengan cara menanyakan kembali kepada peseta didik mengenai hal-hal yang telah dipelajari. Umpan balik bukan hanya pertanyaan yang diajukan oleh pendidik, namun terkadang pertanyaan itu diajukan oleh peserta didik apabila ada materi pelajaran yang belum dimengerti atau dipahami. Kegiatan ini sebenarnya tidak hanya dilakukan pada akhir pelajaran, tetapi juga selama proses belajar mengajar berlangsung. Hal ini dimaksudkan untuk memberikan gambaran kepada pendidik tentang daya serap peserta didik terhadap pelajaran yang telah diterima peserta didik.

Mengakhir kegiatan dengan berdoa: diakhir proses pembelajaran dilakukan doa bersama dan doa yang di ucapkan oleh pendidik tersebut di ikuti oleh peserta didik secara bersama-sama, dan doa yang di ucapkan adalah:"Terima kasih Tuhan engkau telah memberikan kami kekuatan dan kesehatan untuk menerima pelajaran pagi hari ini, saat ini kami telah selasai belajar agama berkatilah kami semua, supaya mendapat nikmati dari tuhan agar kami dapat menerima pelajaran agama pada pagi hari ini, dan dalam nama Yesus kami berdoa haleluya, amin".

\section{Penilaian Pembelajaran}

Penilaian adalah proses pengumpulan informasi untuk mengetahui pencapaian hasil belajar siswa. Penilaian merupakan bagian integral dalam keseluruhan proses belajar mengajar. Penilaian harus dipandang sebagai salah satu faktor yang Menentukan keberhasilan proses dan hasil pembelajaran, bukan hanya sebagai cara untuk menilai hasil belajar siswa.

Evaluasi pembelajaran Pendidikan Agama khususnya Pendidikan Agama Kristen (PAK), merupakan penilaian kegiatan dan kemajuan belajar peserta didik yang dilakukan secara berkala berbentuk ujian, praktikum, tugas, dan atau pengamatan guru. Bentuk ujian meliputi ujian tengah semester, ujian akhir semester, dan ujian tugas akhir dengan memberikan soal-soal secara tertulis. Sedangkan untuk penilaian dalam bentuk peraktekum disamping peserta didik diwajibkan untuk selalu pergi ke gereja untuk setiap minggu, juga di haruskan menghafal beberapa doa.

Kegiatan Praktekum untuk tingkatan SDLB mulai kelas I sampai kelas III belum dituntut untuk menghafal beberapa doa, tapi hanya di berikan pertanyaan tentang "Kapan ke gereja, seperti apa gereja dengan memperlihatkan beberapa gambar rumah ibadah, dapat menyanyikan lagu sekolah minggu". Sedangkan untuk kelas IV keatas di haruskan menghafal 1 ayat dalam Al-Kitab. Untuk jenjang SMALB harus hafal doa bapak kami dan Pengakuan imam Rasuli. Sedangkan untuk jenjang SMPLB peserta didik harus menghafal doa bapak kami.

Selain penilaian dalam bentuk tertulis dan praktek di atas, masih ada beberapa bentuk teknik penilaian yang dapat dijadikan pertimbanngan oleh pendidik dalam memberikan penilaian kepada peserta didik terhadap keberhasilan proses pembelajaran Pendidikan Agama Kristen di SLB Negeri pembina Tingkat Provinsi Papua Kota Jayapura seperti; Pengamatan (observasi), pemberian tugas, dan Hasil Karya.

Pengamatan (observasi): Pendidik senantiasa mengamati tingkat pencapaian perkembangan peserta didik terhadap suatu kegiatan yang 
diberikan, misalnya guru memberikan tugas kepada siswa untuk menbuka Al-Kitab kemudian membaca do’a dalam Al-Kitab, aspek yang diamati oleh pendidik adalah ketepatan siswa dalam menemukan ayat dalam alkitab yang telah diperintahkan oleh pendidik serta tingkat kelancaran dan kefasihan dalam melafazkan setiap kalimat do'a tersebut.

Penugasan: Penilaian hasil belajar siswa melalui penugasan merupakan teknik penilaian yang di lakukan oleh pendidik dengan cara pemberian tugas yang harus dilakukan/dikerjakan siswa dalam waktu tertentu secara perorangan atau kelompok. Ada beberapa materi penugasan yang diberikan seperti; menghafalkan do'a-do'a yang berkenaan dengan materi pelajaran yang dibahas, mencari jenis-jenis perbuatan yang terpuji lewat lembaran kertas yang telah tertulis beberapa kalimat yang telah disusun secara acak, dan mewarnai gambar yang telah disiapkan oleh pendidik.

Hasil Karya: Teknik penilaian ini dilakukan pendidik dengan cara mengumpulkan hasil karya siswa setelah melakukan kegiatan berupa pekerjaan tangan atau karya seni.

\section{P ENUTUP}

Hakekat pelaksanaan pembelajaran Pendidikan Agama Kristen (PAK) di SLB Negeri Pembina Tingkat Provinsi Papua Kota Jayapura, telah terlaksana, namun belum sesuai dengan harapan, hal ini karena belum memiliki tenaga khusus yang mengajarkan materi pendidikan agama yang sesuai dengan kompetensi di bidang pendidikan agama. Untuk memenuhi ketersediaan tenaga pendidik agama tersebut, pihak sekolah hanya menugaskan beberapa tenaga pendidik umum yang dianggap mampu untuk memberikan pelajaran agama. Tenaga pendidik yang mengajar pendidikan agama Kristen mengalami kesulitan dalam memberikan materi pendidikan agama karena tidak memiliki kompetensi di bidang agama, apalagi yang diajar adalah siswa yang memiliki difabel yang membutuhkan penangananan khusus berbeda dengan siswa pada sekolah umum.

Sistem pembelajarannya dilakukan dalam bentuk klasikal dengan menggabungkan seluruh anak difabel untuk setiap tingkatan. Model pembelajaran seperti ini, tentu tidak sesuai dengan karakteristik anak difabel yang seharusnya diklasifasikan berdasarkan jenis difabel serta di berikan perlakuan dengan pendekatan individual. Analisis perangkat pembelajaran (RPP) yang telah dibuat oleh tenaga pendidik agama Kristen di SLB Negeri Pembina telah dijabarkan sesuai dengan pedoman yang merujuk kepada kurikulum KTSP tahun 2006. Namun pada implementasinya ketercapaian Kriteria Ketuntasan Minimal (KKM) terkadang tidak dicapai secara optimal dengan yang telah direncanakan. RPP yang di buat hanya formalitas administrasi sehingga ketercapaian pembelajaran tuntas masih jauh dari harapan. Hal ini disadari karena kondisi peserta didik di SLB membutuhkan strategi khusus dalam penerapan pembelajaran di kelas, yang berbeda dengan peserta didik pada sekolah umum.

\section{UCAPAN TERIMA KASIH}

Terima kasih penulis aturkan kepada Kepala Balai Litbang Agama Makassar yang telah menugaskan penulis untuk melakukan penelitian ini. Kepada kepala Sekolah Luar Biasa Negeri Pembina tingkat Provinsi Papua Kota Jayapura, guru serta siswa terimakasih atas kesediaannya untuk menerima peneliti dala melakukan penelitian ini. Kepada rekan peneliti terimakasih atas masukan bagi perbaikan tulisan ini.

\section{DAFTAR PUSTAKA}

Abdurrahman, Mulyono. 2004. Pendidikan Bagi Anak Berkesulitan Belajar. Jakarta: Depdikbud. Dirjen Dikti, Rhineka Cipta.

Badan Pusat Statistik (BPS). 2011. Kota Jayapura dalam Angka Tahun 2011. Jayapura.

Bogdan, Robert C. \& Sari Knopp Biklen, 1982. Qualittive research for education; Boston: Allyn and Bacon inc.

Haqqo, Eltafiyanal. 2010. Pelaksanaan pembelajaran Pendidikan Agama Islam di SLB PGRI Singojuruh Banyuwangi. http://lib.uinmalang.ac.id/?mod

Hikmawati, Aida. 2010. Pendidikan Agama Islam Bagi Penyandang Cacat Mental di SLB Dharma Rena Ring Putra Nglempongsari Sleman. UIN Sunan Kalijaga Yogyakarta. http://digilib.uinsuka.ac.id/4736/

Mulyono.1994. Pendidikan Luar Biasa Umum. Jakarta: Ditjen Pendidikan Tinggi Depdiknas. Nuraeni, 1997. Intervensi Dini Bagi Anak 
Bermasalah. Jakarta: Cipta Reineke Cipta. Peraturan Menteri Agama Republik Indonesia Nomor 16 Tahun 2010 Tentang Pengelolaan Pendidikan Agama pada Sekolah Pasal 16 Sugiyono, 2005. Metode Penelitian pendidikan Pendekatan Kuantitatif, Kualitatif, dan R\&D.
Bandung: Alfabet.

Thoha, Chabib (eds). 1999. Metodelogi Pengajaran Agama, Yokyakarta: Pustaka Pelajar

Undang-Undang Nomor 23 Tahun 2003 tentang Sistem Pendidikan Nasional 